\title{
Role of tonic GABAergic currents during pre- and early postnatal rodent development
}

\section{Werner Kilb, Sergei Kirischuk* and Heiko J. Luhmann}

Institute of Physiology and Pathophysiology, University Medical Center of the Johannes Gutenberg University, Mainz, Germany

\section{Edited by:}

Alexey Semyanov, RIKEN Brain

Science Institute, Japan

Reviewed by:

Yehezkel Ben-Ari, Institut National de la Santé et de la Recherche Médicale, France

Kai Kaila, University of Helsinki, Finland

\section{*Correspondence:}

Sergei Kirischuk, Institute of Physiology and Pathophysiology, University Medical Center Mainz, Duesbergweg 6, D-55128 Mainz, Germany

e-mail: kirischu@uni-mainz.de
In the last three decades it became evident that the GABAergic system plays an essential role for the development of the central nervous system, by influencing the proliferation of neuronal precursors, neuronal migration and differentiation, as well as by controlling early activity patterns and thus formation of neuronal networks. GABA controls neuronal development via depolarizing membrane responses upon activation of ionotropic GABA receptors. However, many of these effects occur before the onset of synaptic GABAergic activity and thus require the presence of extrasynaptic tonic currents in neuronal precursors and immature neurons. This review summarizes our current knowledge about the role of tonic GABAergic currents during early brain development. In this review we compare the temporal sequence of the expression and functional relevance of different GABA receptor subunits, GABA synthesizing enzymes and GABA transporters. We also refer to other possible endogenous agonists of $\mathrm{GABA}_{A}$ receptors. In addition, we describe functional consequences mediated by the GABAergic system during early developmental periods and discuss current models about the origin of extrasynaptic GABA and/or other endogenous GABAergic agonists during early developmental states. Finally, we present evidence that tonic GABAergic activity is also critically involved in the generation of physiological as well as pathophysiological activity patterns before and after the establishment of functional GABAergic synaptic connections.

Keywords: $\mathrm{GABA}_{A}$ receptor, $\mathrm{GABA}_{B}$ receptor, GABA transporter, GABA metabolism, neuronal proliferation, migration, taurine, review
The GABAergic system is critically involved in neuronal development (e.g., Ben-Ari, 2002; Ben-Ari etal., 2007; Wang and Kriegstein, 2009; Kilb, 2012), influencing virtually all developmental steps from neurogenesis (LoTurco etal., 1995) to the establishment of neuronal connectivity (Wang and Kriegstein, 2008). Since many of these events occur before the onset of synaptogenesis, a tonic, extrasynaptic GABAergic transmission may be important. In the following sections we will first describe the development of the GABAergic system, with special emphasize on all elements that support the particular role of extrasynaptic transmission. Subsequently, we will describe the influence of GABA on various developmental events and present evidence for a critical role of non-synaptic signaling in these processes. In addition, we will summarize observations that demonstrate an important role of extrasynaptic GABAergic transmission in the developing brain after the formation of GABAergic synapses and after onset of GABAergic synaptic transmission. And finally, we like to discuss the origin and nature of additional endogenous GABAergic agonists that mediate extrasynaptic effects during development.

Most studies mentioned in this review describe the development and influence of the GABAergic system during prenatal phases and the first postnatal week in rodents. This period is to some extent comparable to prenatal development in humans (Romijn etal., 1991), although a general comparison of preand perinatal stages between rodents and humans is complicated due the relatively advanced human brain development and the complex expansion pattern of different cortical areas during ontoand phylogenesis (Clancy et al., 2007; Hill et al., 2010). In addition, we like to emphasize that substantial developmental progress occurs during the first postnatal week in rodents and that at one given day of early development, neurons in different cortical regions and layers differ by $2-3$ days in their developmental stage.

\section{DEVELOPMENT OF EXTRASYNAPTIC AND SYNAPTIC GABAergic TRANSMISSION}

Cells in the developing nervous system respond to GABA at surprisingly early stages. The first evidence for this has been found in dissociated cells from the earliest phases of neurogenesis in the turtle brain, which show bicuculline sensitive responses upon GABA application (Shen et al., 1988). In rodents neuronal progenitors in the ventricular zone at embryonic day (E) 15 (LoTurco et al., 1995; Owens et al., 1999) as well as postmitotic migrating neurons (Heck et al., 2007) already reliably show GABAergic responses (Figure 1). In accordance with this early onset of GABAergic responses, the expression of $\mathrm{GABA}_{\mathrm{A}}$ receptors also starts during very early brain development.

$\mathrm{GABA}_{\mathrm{A}}$ receptors are heteropentameric molecules composed of 19 possible subunits $(\alpha 1-6, \beta 1-3, \gamma 1-3, \delta, \varepsilon, \varphi, \pi$, and $\rho 1-3)$. The subunit composition determines GABA affinity, channel conductance and kinetics, pharmacology and subcellular localization of the receptors (Farrant and Kaila, 2007). A few 
A

\section{E16 VZ}

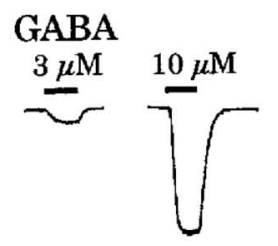

B
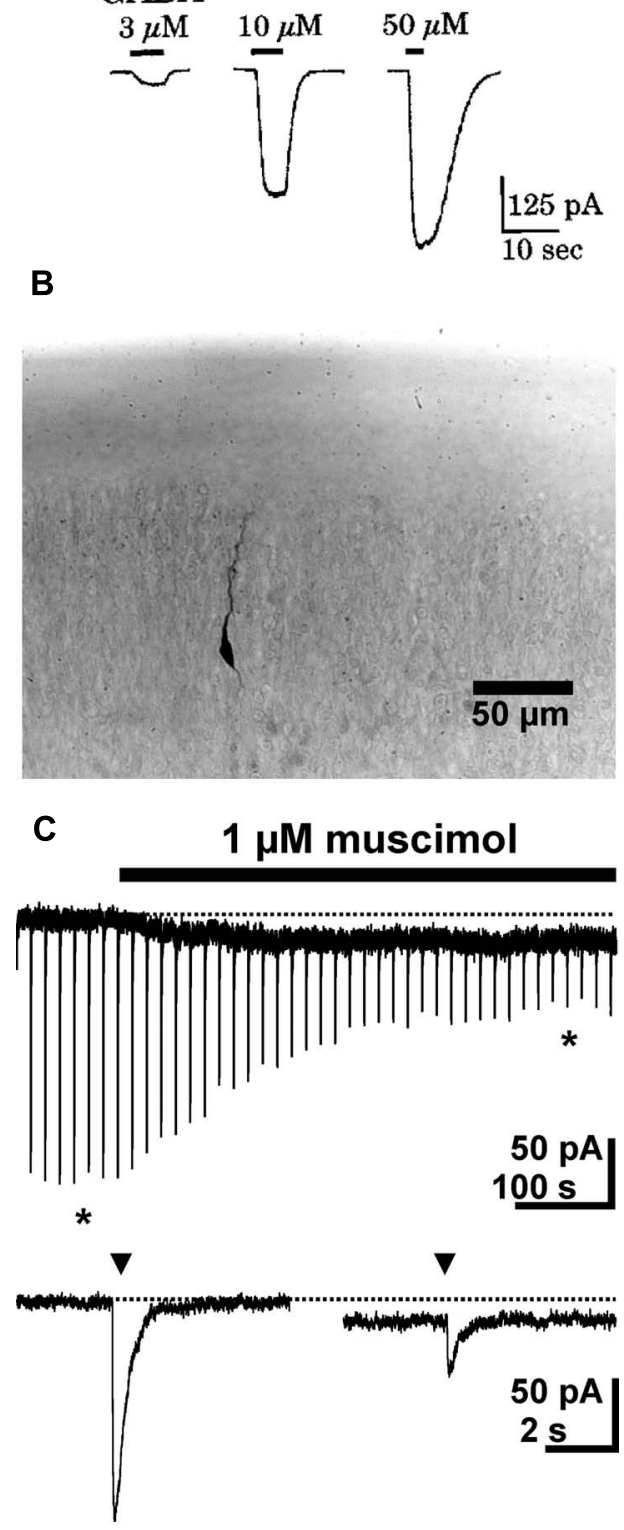

FIGURE 1 | GABAergic currents during early development.

(A) Whole-cell recordings from cells in ventricular zone of embryonic rats (E16) revealed dose-dependent GABAergic currents. (B) Photomicrograph of a biocytin-stained migrating neuron in a P1 rat. (C) Whole-cell recordings show that in migrating neurons a short (2-3 ms) application of $1 \mathrm{mM}$ GABA (triangles) induced fast inward currents, while bath application of $1 \mu \mathrm{M}$ muscimol induced a long lasting tonic current and led to a marked desensitization of phasic responses. The typical responses shown below the continuous trace are marked by asterisks. Pictures taken with kind permission from Owens et al. (1999) (A) and Heck et al. (2007) (B,C).

functional consequences of subtype compositions relevant for this review are (i) in particular the $\gamma 2$ subunit determines the synaptic allocation of $\mathrm{GABA}_{\mathrm{A}}$ receptors, while $\delta$ subunit containing receptors are exclusively located at extrasynaptic sites, (ii) $\alpha 4-6$ and $\rho$ subunit containing receptors have been found predominantly at extrasynaptic localizations, while $\alpha 1-3$ containing receptors are supposed to constitute the synaptic $\mathrm{GABA}_{\mathrm{A}}$ receptors, and (iii) $\delta$ subunit and $\rho$ subunit containing receptors typically reveal a high GABA affinity and a slow and incomplete desensitization, appropriate for a tonic activation by interstitial GABA (reviewed in Farrant and Nusser, 2005; Farrant and Kaila, 2007).

In situ hybridization experiments in the neocortex revealed expression of $\mathrm{GABA}_{\mathrm{A}}$ receptors as early as at $\mathrm{E} 13$ with the appearance of $\beta 3$ subunits in the neuroepithelium (Araki et al., 1992). At E14/E15 $\alpha 3, \alpha 4$ are expressed in the developing cortical layers (Araki et al., 1992; Laurie et al., 1992). Between E15 and E17 $\gamma 2$ subunit mRNA is detected in the neocortex, with the highest expression levels in the cortical plate (CP; Araki et al., 1992; Laurie etal., 1992; Van Eden etal., 1995). At E17 there is evidence that even $\alpha 6$ subunits, which are in the adult brain nearly exclusively located in the cerebellum (Luddens et al., 1990), are expressed in the cortical neuroepithelium (Poulter et al., 1992). In contrast, the $\alpha 1$ subunits characteristic for many mature $\mathrm{GABA}_{\mathrm{A}}$ receptors are expressed relatively late between E19 and P0 (Poulter et al., 1992; Van Eden et al., 1995), while $\delta$ subunit expression is observed only postnatally (Laurie et al., 1992). These observations are supported by northern blot analyses which reveal expression of $\alpha 2$ and $\alpha 4$ at E18 in total brain homogenates, while $\alpha 1$ expression starts only after birth (MacLennan et al., 1991). On the other hand, for precursors of GABAergic interneurons traveling from the lateral ganglionic eminence to the cerebral cortex a stringent up-regulation of $\alpha 1$ and $\gamma 1-3$ subunits occurs after they enter the cortex, which is directly linked to an increase of GABA affinity (Carlson and Yeh, 2011). To our knowledge no study has been published for rodents that investigated the prenatal appearance of different $\mathrm{GABA}_{\mathrm{A}}$ receptor subunits on protein level. However, in rodents at the day of birth ( $\mathrm{P} 0)$ an intense $\alpha 2$ receptor immunoreactivity has been observed in the neocortex, while $\alpha 1$ receptors immunoreactivity is low, but detectable (Fritschy et al., 1994). In the primate neocortex a significant expression of $\alpha 2$, $\alpha 4$, and $\alpha 5$ was observed during prenatal development (Hornung and Fritschy, 1996; Huntsman etal., 1999), while $\alpha 1$ subunits appear shortly before birth and are substantially up-regulated in the first postnatal year (Hornung and Fritschy, 1996).

In the rodent hippocampus expression of mRNA for $\alpha 2$ and $\alpha 5$, but also $\gamma 2$ subunits start at $\mathrm{E} 15$, while $\delta$ subunit mRNA was detected only after birth (Killisch et al., 1991; Laurie et al., 1992; Poulter et al., 1992). At E19 it has been found that neuroepithelial cells or early postmitotic cells in the hippocampus express predominantly $\alpha 4$ and $\alpha 5$ containing $\mathrm{GABA}_{\mathrm{A}}$ receptors (Maric et al., 1999). Expression of $\alpha 1$ subunit mRNA appear only postnatally (Laurie et al., 1992; Poulter et al., 1992). Immunohistochemical studies in the perinatal hippocampus revealed a nearly absence of $\alpha 1$ subunits, while $\alpha 2$ subunits were highly abundant (Fritschy et al., 1994).

Ionotropic GABA receptors constituted of $\rho$ subunits (also termed $\mathrm{GABA}_{C}$ receptors) have a high GABA affinity, slow activation and inactivation kinetics and show little desensitization (Bormann, 2000). In accordance with these properties, they can 
mediate extrasynaptic GABAergic effects (Alakuijala et al., 2006). Expression of $\rho$ subunits has been found in lower neocortical layers of the E15 mouse brain (Fukui et al., 2008) and in the early postnatal hippocampus (Rozzo et al., 2002). In accordance with the early expression of $\rho$ subunits only in lower neocortical layers, functional $\rho$ subunit containing $\mathrm{GABA}_{\mathrm{A}}$ receptors are detected in the intermediate zone (IZ), while they are not expressed in the CP (Denter et al., 2010; Figure 2). The pharmacological properties of these receptors indicate that they most probably are $\rho$ subunits containing heteropentamers, as has been also suggested for interneurons in the adult hippocampus and juvenile CA1 pyramidal neurons (Semyanov and Kullmann, 2002; Hartmann et al., 2004).

In summary, these studies demonstrate that in the cerebral cortex and hippocampus classical $\mathrm{GABA}_{\mathrm{A}}$ and $\rho$ subunit containing GABA receptors are expressed at early developmental stages, and that these receptors probably contain $\alpha 2-\alpha 5$ and $\rho$, but also $\gamma 2$ subunits. Although the expression of $\gamma 2$ subunits typically corresponds to a postsynaptic localization of $\mathrm{GABA}_{\mathrm{A}}$ receptors, the relatively high expression levels of $\alpha 4 / \alpha 5$ and $\rho$ subunits are compatible with extrasynaptic $\mathrm{GABA}_{\mathrm{A}}$ receptors. In contrast, there is compelling evidence that $\delta$ subunits, which are typical for classical extrasynaptic receptors in the immature brain (Farrant and Nusser, 2005), are lacking during early embryonic development.

During embryonic and early postnatal development ionotropic GABA receptors mediate in pyramidal neurons depolarizing membrane responses (Mueller et al., 1984; Ben-Ari et al., 1989; Owens etal., 1996; Lamsa etal., 2000; Achilles etal., 2007; Valeeva etal., 2013). These depolarizing GABAergic responses are caused by $\mathrm{Cl}^{-}$efflux via $\mathrm{GABA}_{\mathrm{A}}$ receptors due to the high intracellular $\mathrm{Cl}^{-}$concentration in developing neurons (BenAri etal., 2012), and play an essential role for the trophic actions of GABA during early development (Ben-Ari, 2002; Represa and Ben-Ari, 2005; Wang and Kriegstein, 2009; Kilb etal., 2011; but see Cancedda etal., 2007). In GABAergic interneurons $\mathrm{GABA}_{\mathrm{A}}$ receptor activation mediate comparable, slightly depolarizing actions in interneurons during early postnatal stages as well as in the adult brain (Banke and McBain, 2006).

In addition to ionotropic GABA receptors, metabotropic $\mathrm{GABA}_{\mathrm{B}}$ receptors are also important elements of the immature GABAergic system. Functional $G_{A B A}$ receptors are heterodimers consisting of $\mathrm{GABA}_{\mathrm{B}} 1 \mathrm{R}$ and $\mathrm{GABA}_{\mathrm{B}} 2 \mathrm{R}$ subunits and are mainly located distant to release sites, suggesting an extrasynaptic activation (Ulrich and Bettler, 2007). A co-localized protein expression of both $\mathrm{GABA}_{\mathrm{B}}$ receptor subunits, and thus presumably also functional $G_{A B A}$ receptors, has been found in hippocampal and cortical regions after E15 (Behar et al., 2001; López-Bendito et al., 2002; Li et al., 2004). Accordingly, evidence for a functional implication of $\mathrm{GABA}_{\mathrm{B}}$ receptors on different developmental events has been demonstrated in the immature neocortex and hippocampus (Behar et al., 2001; López-Bendito et al., 2003; Kirmse and Kirischuk, 2006; McClellan et al., 2007). In the first postnatal week
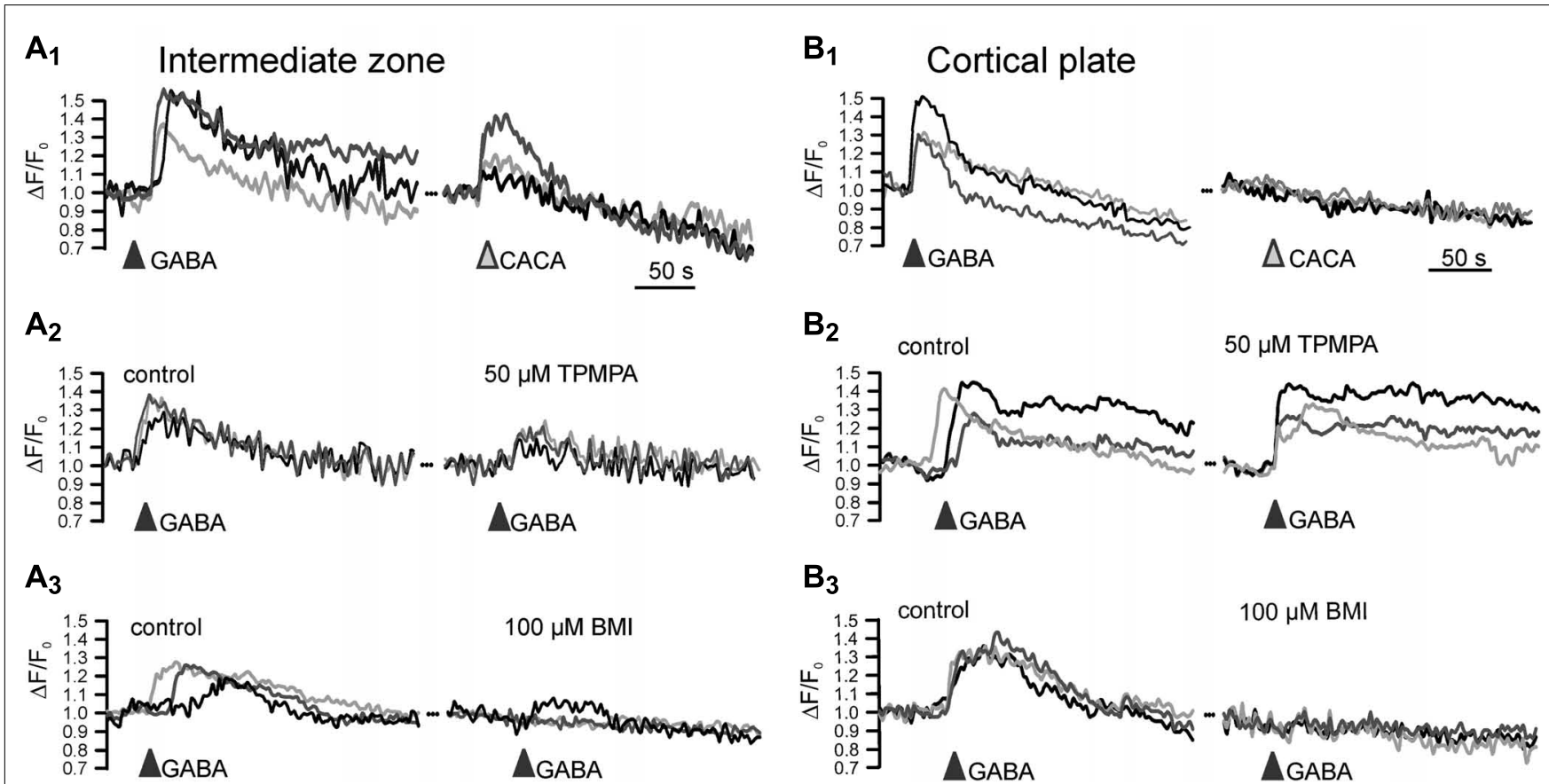

FIGURE 2 | Functional expression of $\rho$ subunit containing GABA receptors in the intermediate zone. Microfluorimetric registration of $\mathrm{Ca}^{2+}$ transients induced by application of $100 \mu \mathrm{M}$ GABA and $100 \mu \mathrm{M}$ of the $\rho$ subunit specific agonist cis-4-amino-crotonic acid (CACA) in neurons from the intermediate zone (A) and cortical plate (B). Note that CACA induced $\mathrm{Ca}^{2+}$

$\mathbf{B}_{3}$

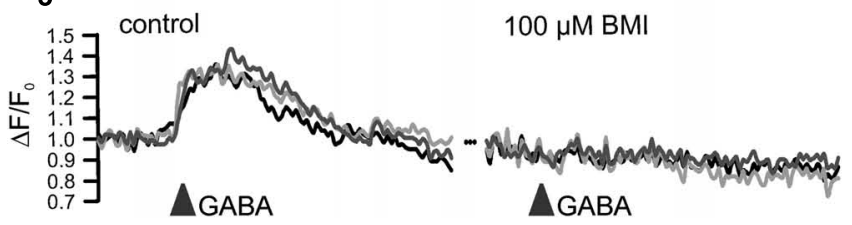

transients occurred only in the intermediate zone $\left(\mathbf{A}_{\mathbf{1}}, \mathbf{B}_{\mathbf{1}}\right)$ that the $\rho$ subunit containing $\mathrm{GABA}_{A}$ receptor antagonist (1,2,5,6-tetrahydropyridin-4-yl)-methylphosphinic acid (TPMPA) was inefficient in the cortical plate $\left(\mathbf{A}_{\mathbf{2}}, \mathbf{B}_{\mathbf{2}}\right)$ and that the $\mathrm{GABA}_{\mathrm{A}}$ antagonist bicuculline (BMI) completely abolished GABAergic $\mathrm{Ca}^{2+}$ transients in the $\mathrm{CP}\left(\mathbf{A}_{\mathbf{3}}, \mathbf{B}_{\mathbf{3}}\right)$. Modified from Denter et al. (2010). 
a reliable presynaptic effect of $\mathrm{GABA}_{\mathrm{B}}$ receptors is observed in the rodent neocortex and hippocampus, while a postsynaptic current is less developed (Luhmann and Prince, 1991; Fukuda et al., 1993; Gaiarsa et al., 1995).

A peculiar observation of the in situ hybridization studies for $\mathrm{GABA}_{\mathrm{A}}$ receptor subunits was the early expression of $\gamma 2$ subunits, which are implicated in synaptic clustering of $\mathrm{GABA}_{\mathrm{A}}$ receptors, during early embryonic stages. However, $\gamma 2$ subunits mediate the postsynaptic clustering of $\mathrm{GABA}_{\mathrm{A}}$ receptors via an interaction with the scaffolding proteins gephyrin and collybistin (Kneussel and Betz, 2000; Mukherjee et al., 2011). While gephyrin is expressed at high levels in the neuroepithelium already at E14, collybistin expression was observed in the cortical anlage only in regions with postmitotic neurons, which strongly suggests that $\mathrm{GABA}_{\mathrm{A}}$ receptors cannot form postsynaptic clusters in the ventricular and subventricular zones and on migrating neurons (Kirsch et al., 1993; Kneussel et al., 2001).

GABA required for the activation of these GABA receptors can originate either from GABAergic neurons or GABAergic fibers. GABAergic interneurons are generated in rodents mainly in the medial and caudal ganglionic eminence and migrate tangentially to the neocortex and hippocampus (Anderson et al., 1997; Pleasure etal., 2000; Miyoshi etal., 2010), where they, depending on their origin, differentiate in the diverse types of GABAergic interneurons (Tricoire et al., 2011). In the human neocortex a substantial fraction of the GABAergic interneurons is, however, generated in the ventricular zone of the dorsal pallium (Petanjek et al., 2008; Yu and Zecevic, 2011). The first GABA positive neurons are detectable in the primordial plexiform layer of the cortical anlage already at E12 (Del Rio et al., 1992). In subsequent embryonic stages GABAergic neurons are abundant in all layers of the developing cortex between the marginal zone and the subventricular zone (Lauder et al., 1986; Van Eden et al., 1989; Cobas et al., 1991; Del Rio et al., 1992). In the human neocortex the first GABAergic neurons were detected at gestational week 6.5 even before the appearance of the CP (Zecevic and Milosevic, 1997). In the rodent hippocampus GABAergic interneurons were first detected between E14 and E16 in the inner marginal zone, the subplate and the subventricular zone (Soriano et al., 1994; Kanold and Luhmann, 2010). In addition to this early appearance of GABAergic neurons, a dense network of GABAergic fibers originating from extracortical regions reach the cortical anlage during these early embryonal stages even before the appearance of GABAergic neurons (Lauder etal., 1986; Del Rio etal., 1992; Ma and Barker, 1995).

GABA is mainly produced by the glutamic acid decarboxylases (GAD), which is expressed in two major isoforms. GAD-65 is considered to mediate the production of GABA intended for synaptic release, while GAD-67 is supposed to maintain cytoplasmic GABA levels (Soghomonian and Martin, 1998). In the rodent neocortex expression of GAD-67 is detectable at E15 (Ma and Barker, 1995) in the germinal zone of the cortical anlage, while GAD-65 occurs delayed and is observable only after P6 (Kiser et al., 1998). In the hippocampus both GAD-65 and GAD-67 protein could be detected at E18, with both isoforms expressed mainly at somatic locations during prenatal development (Dupuy and Houser, 1996). Expression of GAD has also been found in fetal human brain before gestational week 15 (Das and Ray, 1997), when GAD-67 is the prominent isoform (Chan et al., 1997). Thus in particular a somatic generation of GABA can appear during early stages of corticogenesis. In contrast, the GABA degrading enzymes GABA transaminase and succinate semialdehyde dehydrogenase reveal low expression levels in the pre- and early postnatal rodent neocortex (Pitts and Quick, 1967; Kristt and Waldman, 1986), suggesting that a substantial portion of GABA is distributed within the CNS via the interstitium.

For synaptic release GABA must be accumulated in transmitter vesicles by the vesicular inhibitory amino acid transporter (vIAAT) or vesicular GABA transporter (vGAT; Wojcik et al., 2006). At $\mathrm{P} 0$ the expression of vGAT in the neocortex is rather low and mostly restricted to fibers (Minelli et al., 2003). In the rodent hippocampus GABAergic inputs were observed before birth in about $75 \%$ of pyramidal neurons at P0 and in $65 \%$ of interneurons (Tyzio et al., 1999; Hennou et al., 2002), indicating the early appearance of functional GABAergic synapses, but also that synaptic spillover may be a source of extrasynaptic GABA receptor activation. No GABAergic synaptic responses were observed in proliferative regions of the cerebral cortex (Owens et al., 1999). On the other hand, reliable tonic GABAergic currents were found in the embryonic neocortical neurons in the ventricular zone (LoTurco et al., 1995) and the CP (Owens et al., 1999), and in neuronal cultures of embryonic hippocampal neurons (Valeyev et al., 1998). These observations indicate that GABAergic responses precede synaptic GABAergic transmission, strongly suggesting that non-synaptic transmission plays an important role during prenatal development. Indeed, there is compelling evidence that during these stages a substantial part of basal, but also of stimulated GABAergic transmission occur via non-vesicular release (Demarque et al., 2002). The tonic GABAergic currents observed in neuronal cultures of embryonic hippocampal neurons suggest that hippocampal neurons itself can be a source of GABA in these cells (Valeyev etal., 1998). Subsequent in vitro experiments revealed that isolated neurons from the $\mathrm{CP}$ can release GABA in sufficient large amounts to obtain micromolar concentrations in the supernatant (Behar etal., 2001). In immature neocortical slices an extracellular GABA concentration of 250-500 nM, and thus sufficiently high to activate high affinity ionotropic GABA receptors or $\mathrm{GABA}_{\mathrm{B}}$ receptors has been found (Cuzon etal., 2006; Dvorzhak etal., 2010).

Possible candidates for a non-vesicular GABA release are GABA transporters (GATs). In the adult nervous system these transporters mediate the uptake of GABA from interstitial space, show mainly a neuronal localization of the GAT-1 isoform and mainly glial localization of GAT-3 isoform (Borden, 1996). Accordingly these two subtypes are responsible for controlling extracellular GABA from vesicular and non-vesicular sources, respectively (Song et al., 2013). However, these transporters can also act in reverse mode and thus release GABA from cells (Richerson and Wu, 2003; Kirischuk and Kilb, 2012). In particular the high intracellular $\mathrm{Cl}^{-}$concentration in immature neurons, which directly influences GAT mediated GABA transport by determining the reversal potential of this $\mathrm{Cl}^{-}$dependent transmembrane 
transporter, can result in less efficient uptake or even a reversal of the transport mode (Kirischuk and Kilb, 2012). In the mouse brain GAT-1 expression starts at E14 in the medial ganglionic eminence and is detected at E16 in the neocortical subventricular zone (Evans et al., 1996). GAT-3 is already expressed in the neocortical subventricular zone at E14 (Evans et al., 1996). In contrast, in the developing hippocampus GAT-1 expression is low at early postnatal age, with GAT-3 expression dominating (Evans et al., 1996). Interestingly, between the end of the first postnatal week and the end of the first postnatal month a transient somatic location of GAT-1 expression has been demonstrated in the rat neocortex and hippocampus (Yan et al., 1997). In addition, in the immature rat cortex GAT-1 is abundant in astrocytes and GAT-3 in neurons (Yan et al., 1997; Minelli et al., 2003), despite the mainly neuronal localization of GAT-1 and the mainly glial localization of GAT-3 in the adult CNS (Borden, 1996; Conti et al., 2004). Both observations suggest a substantial shift in the functional role of GAT during development. A direct implication of GAT-1 for GABA release has been demonstrated in tangentially migrating precursors of GABAergic interneurons (Poluch and Konig, 2002), where glutamatergic activation leads to a nonvesicular GABA release by a $\mathrm{Na}^{+}$-increase driven reversal of the GAT-1 transporter (Pin and Bockaert, 1989). On the other hand, in cortical neuroblasts the activity dependent GABA release does not depend on GATs (Liu et al., 2005), indicating that additional, currently unknown pathways may contribute to non-vesicular GABA release during early development. And finally, it has been shown for the early postnatal hippocampus and neocortex that GAT-1 is already effectively removing GABA from the extracellular space and thereby directly regulates tonic GABAergic currents and affects intrinsic neuronal activity (Sipila et al., 2004, 2007; Bragina et al., 2008).

Overall, these studies suggest that in the immature neocortex and hippocampus all essential elements for functional GABAergic transmission appear at very early stages, while the elements for reliable synaptic GABA release and $\mathrm{GABA}_{\mathrm{A}}$ receptor clustering occur at later developmental stages. In summary, these findings indicate that activation of extrasynaptic GABAergic receptors underlies the diverse trophic actions of GABA during early neuronal development.

\section{INFLUENCE OF EXTRASYNAPTIC GABAergic TRANSMISSION ON CRITICAL EVENTS DURING PRE- AND EARLY POSTNATAL DEVELOPMENT}

GABA has been considered as a major neurotrophic factor during embryonic development (Varju et al., 2001; Owens and Kriegstein, 2002; Represa and Ben-Ari, 2005; Wang and Kriegstein, 2009). Different developmental events, ranging from proliferation to the establishment of mature synaptic circuits depend on GABA, with a substantial portion of these events occurring without a major contribution of synaptic processes.

Application of GABAergic agonists increases DNA synthesis and the proliferation of neuroblasts in the ventricular zone, whereas it decreases proliferation in the subventricular zone (LoTurco etal., 1995; Haydar etal., 2000). Most probably the majority of these neuronal progenitors in the ventricular zone are radial glial cells (Noctor et al., 2001), on which functional GABA receptors have been reported (Noctor et al., 2002). While alterations in proliferation induced by the external GABA application demonstrate that GABA has the potential to directly interfere with neurogenesis, the observation that inhibition of $\mathrm{GABA}_{\mathrm{A}}$ receptors induces the opposite effect clearly shows that endogenously released GABA regulates neurogenesis in ventricular and subventricular zones (LoTurco et al., 1995; Haydar et al., 2000). In addition to $\mathrm{GABA}_{\mathrm{A}}$ receptors, it has been also shown that $\mathrm{GABA}_{\mathrm{B}}$ receptors are involved in controlling neurogenesis (Fukui et al., 2008) and gliogenesis (Luyt et al., 2007). It can be assumed that extrasynaptic GABAergic transmission influences these processes, since in both layers synaptic GABA release has not been reported so far. This mechanism has been documented in adult neurogenesis, where GABAergic neuroblasts in the subventricular zone release GABA via non-vesicular mechanisms, which in turn impede the proliferative activity of glia-derived progenitor cells (Liu et al., 2005). In addition, it could be shown that during adult neurogenesis $\alpha 4$ subunit containing GABA receptors are involved in the regulation of neurogenesis (Duveau et al., 2011), which also suggests that extrasynaptic transmission is essential. Neurogenesis in the neocortex is also impeded by glutamate, and this glutamatergic inhibition of proliferation of glutamatergic pyramidal neurons is supposed to serve as a feedback mechanism to control the number of excitatory neurons (Wang and Kriegstein, 2009). However, because in rodents the ventricular and subventricular zones of the cortical anlage do not give rise to GABAergic interneurons, the functional role of GABAergic control of proliferation is probably more complicated.

In the mammalian brain the neurotransmitter phenotype of neurons is determined by different transcription factors and is normally established with neurogenesis (Ma, 2006). The observation that granule cells of the dentate gyrus can switch their neurotransmitter phenotype in an activity dependent manner (Romo-Parra et al., 2003), suggest that during neuronal development the expression of transcription factors may also be affected by neurotransmitters and their receptors. In the central nervous system of Xenopus it has already been shown that GABA can directly influence neurotransmitter specification via $G_{A B A}$ receptors (Root et al., 2008), however, for mammalian species it has not been demonstrated yet whether GABA receptors can influence the neurotransmitter phenotype.

A variety of in vitro and in vivo studies reported that GABA is an important determinant of neuronal migration, acting as chemoattractant, regulating cell mobility and influencing initiation and termination of the migration process (Behar et al., 1996; Heng etal., 2007; Manent and Represa, 2007). A selective inhibition of $\mathrm{GABA}_{\mathrm{A}}$ receptors enhances radial migration in neocortical organotypic slice cultures (Behar et al., 2000; Heck etal., 2007) and in vivo induces severe cortical malformations leading to upper cortical heterotopia (Heck et al., 2007), suggesting that $\mathrm{GABA}_{\mathrm{A}}$ receptors provide a stop signal for migrating neurons (Figure 3A). In contrast, specific inhibition of $\rho$ subunit containing $\mathrm{GABA}_{\mathrm{A}}$ receptors or a simultaneous inhibition of both subclasses of $\mathrm{GABA}_{\mathrm{A}}$ receptors impedes radial migration (Behar etal., 2000; Denter etal., 2010), suggesting that $\rho$ subunit containing $\mathrm{GABA}_{\mathrm{A}}$ receptors support the migration out of deeper cortical layers (Figure 3B). Functional $\rho$ subunit containing 


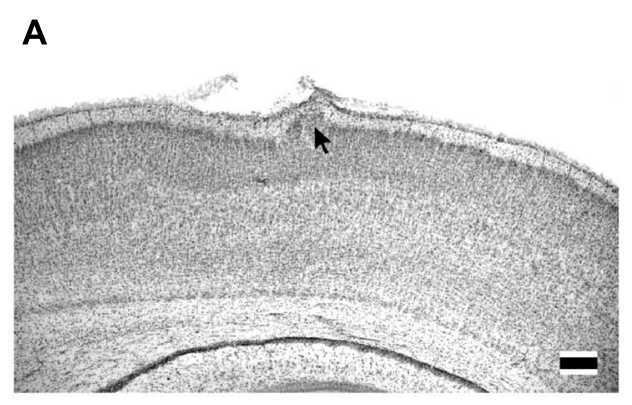

B

GABA

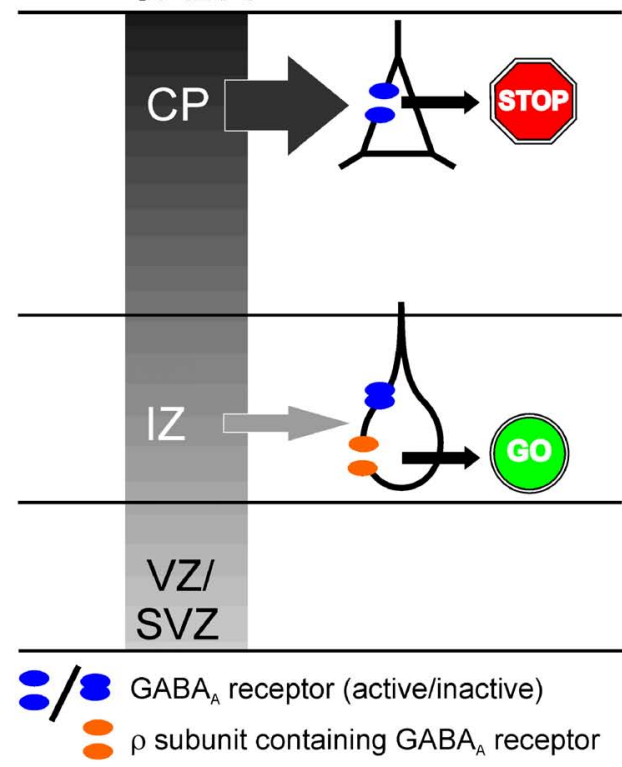

FIGURE 3 | Influence of GABA $_{A}$ receptors on migration. (A) Migration defect induced by $\mathrm{GABA}_{A}$ receptor inhibition in vivo. Digital photograph of 50- $\mu \mathrm{m}$-thick Nissl-stained coronal sections showing a heterotopia (arrow) of a P7 rat treated with a BMI loaded Elvax implant at P0. Scale bars correspond to $200 \mu \mathrm{m}$. (B) Schematic drawing illustration the effect of classical and $\rho$ subunit containing $\mathrm{GABA}_{A}$ receptors on radial migration in the developing neocortex. The gray gradient represents the outside directed GABA gradient. In the intermediate zone (IZ) migrating neurons express classical $G_{A B A}$ and $\rho$ subunit containing $G_{A B A}$ receptors. In the cortical plate $(C P)$ only classical $G A B A_{A}$ receptors are found. Due to the outside directed GABA gradient the low-affinity classical $G_{A B A}$ receptors are only activated in the $\mathrm{CP}$, where they contribute to termination of migration (STOP sign). The lower GABA concentration in the IZ is only sufficient to activate the high affinity $\rho$ subunit containing $G A B A_{A}$ receptors, which is necessary to support migration in the IZ (GO sign). Modified from Heck etal. (2007) (A) and Denter etal. (2010) (B).

$\mathrm{GABA}_{\mathrm{A}}$ receptors are only found in the subcortical regions of the developing cortex that lack evidence for synaptic release (Denter et al., 2010), indicating that they are predominantly activated by non-synaptically released GABA. Since so far no synaptic inputs on migrating neurons have been demonstrated, it has been suggested that the stop signal for migrating neurons is mediated by the higher interstitial GABA concentrations in superficial layers of the developing cortex (Behar et al., 2000). Despite the different effects of both subclasses of $\mathrm{GABA}_{\mathrm{A}}$ receptors on radial migration, the effect of ionotropic GABA receptors on migration is most probably mediated by depolarization-induced $\mathrm{Ca}^{2+}$ transients, which are essential for the induction and maintenance of radial migration (Komuro and Rakic, 1996, but see Cancedda et al., 2007). In addition, it has been demonstrated that GABA facilitates the tangential migration of GABAergic interneurons to the appropriate neocortical locations via $\mathrm{GABA}_{\mathrm{A}}$ receptors (Cuzon et al., 2006; Inada et al., 2011). Metabotropic $G_{A B A}$ receptors stimulate the transition of radially migrating neurons from the IZ to the $\mathrm{CP}$ (Behar et al., 2001) and mediate the migration of interneurons to their appropriate locations in the neocortex during embryonic stages (López-Bendito et al., 2003). In the immature hippocampus $\mathrm{GABA}_{\mathrm{A}}$ receptors promote radial migration (Manent et al., 2005). Importantly, neuronal migration is unaffected in animals in which the synaptic release is completely suppressed (Manent et al., 2005), again emphasizing the essential role of non-synaptically released GABA acting on extrasynaptic receptors for neuronal migration in the hippocampus.

GABA also exerts a direct effect on neurite growth and axon elongation (see Sernagor et al., 2010 for review). A variety of studies demonstrated that GABA application promotes the outgrowth and ramification of dendrites in neocortical and hippocampal neurons (e.g., Barbin et al., 1993; Maric et al., 2001). This dendrite promoting effect of GABA relies on depolarizing GABAergic responses and subsequent $\mathrm{Ca}^{2+}$ signals (Maric et al., 2001; Cancedda et al., 2007; Wang and Kriegstein, 2008). Dendritic ramification is inhibited by GABAergic antagonists (Maric et al., 2001), indicating that endogenous GABA is required for normal neurite formation. The cell culture studies of Maric et al. (2001) convincingly showed that not only blocking $\mathrm{GABA}_{\mathrm{A}}$ receptors, but also inhibition of GAD severely impairs dendrite formation, which strongly suggests that an autocrine release of GABA acting on extrasynaptic $\mathrm{GABA}_{\mathrm{A}}$ receptors is required for this effect. In cell cultures from embryonic cortical neurons axonal growth is also accelerated by $\mathrm{GABA}_{\mathrm{A}}$ receptor activation via $\mathrm{Ca}^{2+}$ and calmodulin-dependent kinase 1 activation (Ageta-Ishihara et al., 2009). Since this effect is reversed by $\mathrm{GABA}_{\mathrm{A}}$ receptor antagonists and axon extension partly occurs before the appearance of synaptic GABA release, it has been suggested that tonic GABAergic effects also contribute to the facilitating GABA effect on axon extension (Sernagor et al., 2010). Activation of presynaptic $\mathrm{GABA}_{\mathrm{B}}$ receptors is required to stabilize developing GABAergic synapses of basket cells in the mouse occipital neocortex (Fu et al., 2012). On the other hand, it has been shown that already in the immature hippocampus and neocortex tonic activation of presynaptic $\mathrm{GABA}_{\mathrm{B}}$ receptors reduces GABA release (Safiulina and Cherubini, 2009; Dvorzhak et al., 2010).

Subsequent developmental events are also directly influenced by GABAergic signaling. For example it has been shown that depolarizing GABAergic responses are essential for synaptogenesis (Wang and Kriegstein, 2008). But because these events occur mostly after the onset of synaptogenesis and after the functional expression of GABAergic synaptic inputs (e.g., Owens et al., 1999; Tyzio et al., 1999; Hennou et al., 2002; Kilb et al., 2004), synaptic GABAergic effects may dominate these events. However, it has been shown that this GABAergic influence on synaptogenesis is closely linked to $N$-methyl-D-aspartate (NMDA) 
receptors (Wang and Kriegstein, 2008). In immature neurons the $\mathrm{Mg}^{2+}$ block from NMDA receptors is released by an GABAergic depolarization before 2-amino-3-(3-hydroxy-5-methyl-isoxazol4-yl)propanoic acid (AMPA) mediated synaptic inputs appear (Leinekugel et al., 1997), leading to spontaneous correlated network activity, which is typical for the developing brain (Ben-Ari et al., 1989; Garaschuk et al., 1998; Dupont et al., 2006) and which probably plays an essential role for the maturation of neuronal networks (see Khazipov and Luhmann, 2006; Ben-Ari et al., 2007; Kilb et al., 2011 for review). But since tonic GABAergic currents are essential to drive such events in the immature hippocampus (Sipila et al., 2005), it can be assumed that tonic GABAergic currents continue to contribute to the trophic GABA action even after the onset of GABAergic synaptic transmission.

In summary, these studies provide convincing evidence that tonic GABAergic currents control the genesis, migration and differentiation of neurons during early development. All these events occur either before the onset of synaptic GABAergic transmission or in neurons that do not receive synaptic inputs, indicating that extrasynaptic GABAergic signaling is essential for these processes. Beside this correlative indication, the studies by Maric et al. (2001); Liu et al. (2005), and Manent et al. (2005) provide strong evidence for the important role of non-synaptically released GABA on neurogenesis, migration, and differentiation. An additional evidence for the dominating role of non-vesicular released GABA on cortical development is the observation that no anatomical abnormalities are detected in the neocortex of vGAT knockout mice, in which synaptic GABA release is absent (Wojcik et al., 2006). Similarly, a normal neocortical appearance, dendritic arborization and even synaptic structure has been described in perinatal mice after complete suppression of synaptic release in munc-18 knockout mice (Verhage et al., 2000; Demarque et al., 2002), again emphasizing the role of non-vesicular release and extrasynaptic receptors for early neuronal development.

\section{TONIC CURRENTS REGULATE EXCITATION AFTER GABAergic SYNAPTOGENESIS}

Tonic GABAergic currents also strongly influence the activity of the immature nervous system after the onset of synaptic activity. As discussed above, in particular the different subunit composition of $\mathrm{GABA}_{\mathrm{A}}$ receptors or distinct distribution and transport modes of GATs can contribute to these age-dependent effects. For instance in the rodent hippocampus $\alpha_{5}$ subunit expression (Ramos et al., 2004) and, correspondingly, tonic GABAergic currents (Holter et al., 2010) are up-regulated during the first postnatal week. Due to the depolarizing GABAergic responses during these stages (BenAri etal., 2012), these tonic GABAergic currents increase the excitability of the immature hippocampus (although GABAergic responses can mediate shunting inhibition even at depolarizing potentials; Kolbaev et al., 2011). Accordingly, early network oscillations in the hippocampus, which depend on glutamatergic transmission and membrane properties of intrinsically bursting pyramidal neurons (Ben-Ari et al., 1989; Bolea et al., 1999; Sipila et al., 2006), are driven by a tonic GABAergic depolarization of these cells (Sipila et al., 2005). In the early postnatal hippocampus tonic GABAergic currents, mediated by $\alpha 5$ and $\gamma 2$ subunit containing GABA receptors, enhance the excitability of pyramidal neurons, but not of interneurons (Marchionni et al., 2007). Interestingly, in the adult hippocampus moderate tonic currents are more prominent in interneurons and can even promote excitation in these cells (Semyanov et al., 2003), although $\mathrm{GABA}_{\mathrm{A}}$ receptor activation mediate similar, slightly depolarizing actions in interneurons at both developmental stages (Banke and McBain, 2006). Due to this slight depolarizing action, moderate tonic currents mediate an excitatory action in mature hippocampal interneurons, while shunting inhibition dominates at larger tonic conductances a (Song et al., 2011).

In the immature hippocampus a moderate increase in tonic GABAergic currents mediated by $\alpha 5$ containing receptors promote epileptiform discharges under low- $\mathrm{Mg}^{2+}$ condition, which are insufficient to induce epileptiform discharges in this preparation (Kolbaev et al., 2012; Figure 4). In the hippocampus of early postnatal rats a tonic activation of $\mathrm{GABA}_{\mathrm{B}}$ receptors does not control basal or stimulated GABA release (Caillard et al., 1998), although the $\mathrm{GABA}_{B}$ specific agonist Baclofen reduces the amplitude of GABAergic postsynaptic currents, indicating the functional expression of $\mathrm{GABA}_{\mathrm{B}}$ receptors in this structure (Caillard et al., 1998). In contrast, it has been shown that a tonic activation of $\mathrm{GABA}_{\mathrm{B}}$ receptors decreases neurotransmitter release in GABAergic synapses in early postnatal hippocampus and neocortex (Safiulina and Cherubini, 2009; Dvorzhak et al., 2010). This observation indicates that ambient GABA can mediate a stringent feedback control via $G_{A B A}$ receptors during a developing stage when GABA can generate excitatory responses (Ben-Ari, 2002; Valeeva et al., 2010). In addition, these presynaptic GABA $\mathrm{B}$ receptors may also limit the amount of ambient GABA originating from synaptic release. However, in summary these results demonstrate that a tonic activation of $\mathrm{GABA}_{\mathrm{A}}$ receptors can increase the excitability in early postnatal circuits.

\section{ORIGIN AND NATURE OF ENDOGENOUS GABAergic AGONISTS}

The important role of GABA for neuronal development was challenged by the observation that even a complete knockout of both GAD-65 and GAD-67 did not induce gross disturbances in the neocortex and hippocampus until $\mathrm{P} 0$, albeit a virtually absence of GABA in the brains of these animals (Ji et al., 1999). Although this study may refute the importance of GABA as neurotrophic substance during prenatal development, it can also indicate that other factors can compensate the lack of GABA or even represent an additional important trophic neurotransmitter during early corticogenesis.

In this respect it is important to reconsider that most studies investigating tonic currents identify such current by the blockade of $\mathrm{GABA}_{\mathrm{A}}$ receptors and thus cannot provide any information about the nature of the endogenous ligand of extrasynaptic GABA receptors. One intriguing candidate for such a substance is taurine, which is an agonist of $\mathrm{GABA}_{\mathrm{A}}, \mathrm{GABA}_{\mathrm{B}}$, and glycine receptors (Albrecht and Schousboe, 2005). In rat and human fetal brain taurine is the most abundant neurotransmitter (Das and Ray, 1997; Benitez-Diaz et al., 2003). In early postnatal cortex a glycinergic agonist, presumably taurine, is released upon electrical stimulation in a $\mathrm{Ca}^{2+}$ and action potential independent manner (Flint et al., 1998) and in the presence of a hypoosmolar solution (Flint 


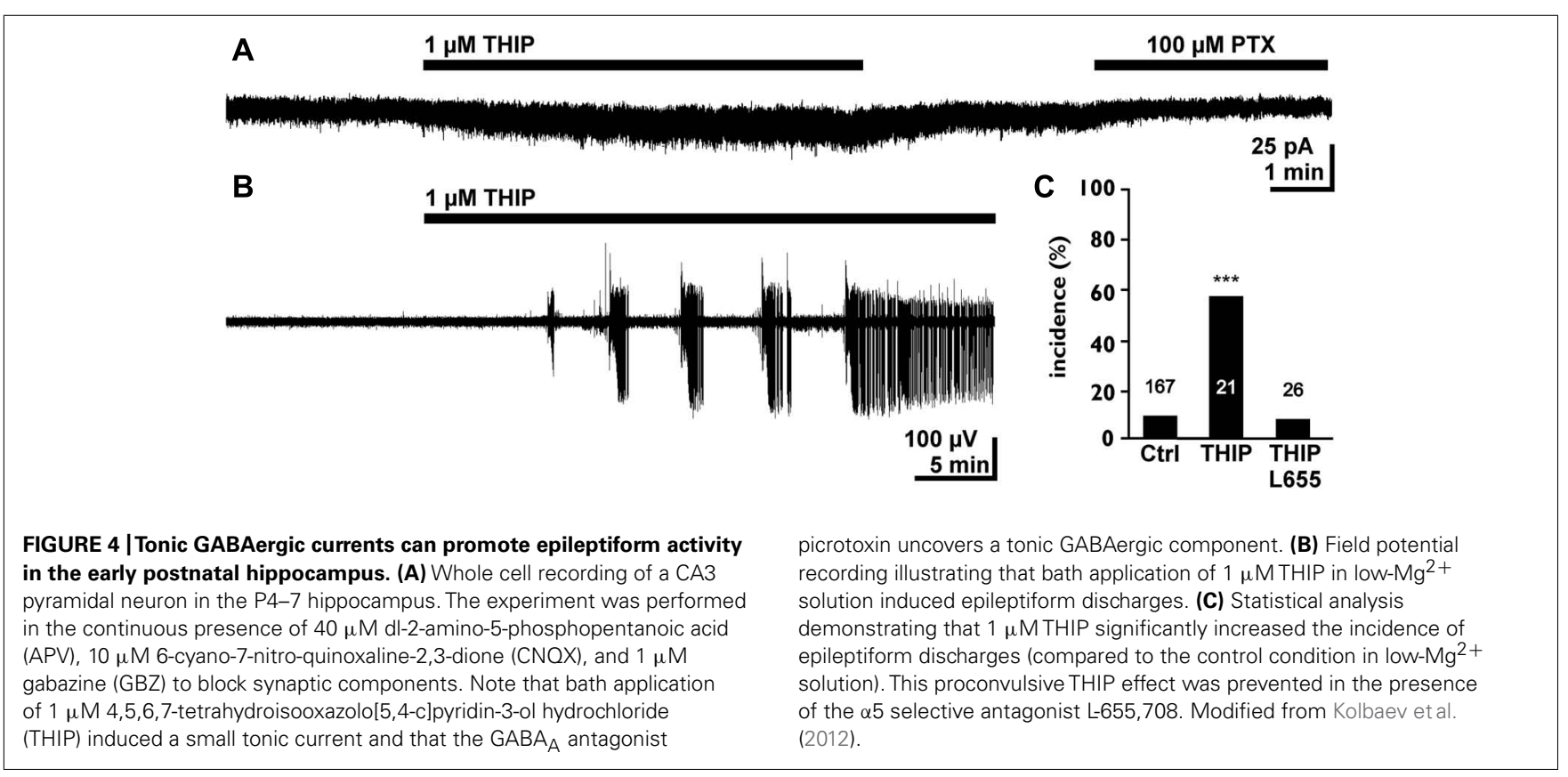

et al., 1998; Kilb et al., 2008), indicating that taurine can be release in the immature central nervous system (CNS) mainly by nonsynaptic processes. Possible release pathways are volume-sensitive organic osmolyte channels or a reversal of the taurine transporter (Ando et al., 2012). Analysis of the chemoattractant diffusible factors released by the CP neurons also identified taurine as a possible candidate (Behar et al., 2001) and it has been shown by the same authors that taurine modulates radial migration via activation of $\mathrm{GABA}_{\mathrm{B}}$ receptors (Behar et al., 2001). In accordance with these in vitro studies, migration deficits have been found in kittens born from taurine-deficient mothers (Palackal et al., 1986). Taurine may, however, act mainly as an agonist for glycine receptors, which have been found in the immature CNS (Wu etal., 1992; Flint et al., 1998; Kilb et al., 2002; Okabe et al., 2004); which are supposed to be mainly activated by non-synaptically released taurine (Mori et al., 2002) and which are also directly involved in early developmental events like migration (Nimmervoll et al., 2011).

However, the exact concentrations of interstitial GABA and taurine are unknown, since most reports document only total neurotransmitter contents. Considering the lack of vGAT and synaptic release during early development and the high intracellular taurine concentration, the abundance of taurine in the interstitial space may be considerably higher than that of GABA. On the other hand, the amount of taurine released by CP neurons is similar to the GABA release (Behar et al., 2001), indicating that at least in this niche GABA will by its substantially higher affinity to both $\mathrm{GABA}_{\mathrm{A}}$ and $\mathrm{GABA}_{\mathrm{B}}$ receptors mediate a more pronounced effect.

Overall, the observations summarized in this review indicate (i) that the molecular constituents of the GABAergic system are present at very early developmental stages before the onset of synaptogenesis, (ii) that tonic GABAergic currents are acting in the developing CNS, (iii) that GABA mediates a trophic action on neurogenesis, neuronal migration and differentiation in developmental niches which lack synaptic GABAergic signaling, and (iv) that tonic GABAergic currents regulate neuronal activity even after the establishment of reliable GABAergic synaptic transmission. In summary, all these studies provide compelling evidence for the important role of extrasynaptic GABAergic signaling during early neuronal development. Accordingly, it has been found that substances, which interfere with the GABAergic system during such early developmental stages, and thus affect mostly non-synaptic processes, disturb the proper development of the central nervous system. For example, antiepileptic drugs acting on GABA mechanisms lead to hippocampal and neocortical dysplasias, most probably by disturbing proliferation and radial migration (Manent et al., 2007). Similarly, prenatal exposure to ethanol, which is supposed to act partially via an activation of $\delta$ subunit containing receptors (Brickley and Mody, 2012), leads to a decreased proliferation (Jacobs and Miller, 2001) and migration (Cuzon et al., 2008) of cortical neurons. These examples demonstrate that the important role of extrasynaptic GABAergic signaling during neuronal development has to be considered in therapeutical intervention during pregnancy. On the other hand, the early expression of different elements of the GABAergic system during very early stages of neuronal development emphasizes the close interaction between genetic programs and functional responses of neuronal progenitors or neuroblasts. To elucidate how genetic programs determine the electrical properties of the developing nervous system and how, vice versa, the tonic activation of neurotransmitter receptors influence the transcription of genes will be essential questions for the further comprehension of early neuronal development.

\section{ACKNOWLEDGMENT}

Supported by grants of the Deutsche Forschungsgemeinschaft to the authors. 


\section{REFERENCES}

Achilles, K., Okabe, A., Ikeda, M. Shimizu-Okabe, C., Yamada, J., Fukuda, A., et al. (2007). Kinetic properties of $\mathrm{Cl}$ uptake mediated by $\mathrm{Na}^{+}$-dependent $\mathrm{K}^{+}-2 \mathrm{Cl}$ cotransport in immature rat neocortical neurons. J. Neurosci. 27, 8616-8627. doi: 10.1523/JNEUROSCI.5041-06.2007

Ageta-Ishihara, N., Takemoto-Kimura, S., Nonaka, M., Adachi-Morishima, A., Suzuki, K., Kamijo, S., etal. (2009). Control of cortical axon elongation by a GABAdriven $\mathrm{Ca}^{2+} /$ calmodulin-dependent protein kinase cascade. J. Neurosci. 29, 13720-13729. doi: 10.1523/ JNEUROSCI.3018-09.2009

Alakuijala, A., Alakuijala, J., and Pasternack, M. (2006). Evidence for a functional role of GABA-C receptors in the rat mature hippocampus. Eur. J. Neurosci. 23, 514-520. doi: 10.1111/j.1460-9568.2005.04572.x

Albrecht, J., and Schousboe, A. (2005). Taurine interaction with neurotransmitter receptors in the CNS: an update. Neurochem. Res. 30, 16151621. doi: 10.1007/s11064-005-89 86-6

Anderson, S. A., Eisenstat, D. D., Shi, L., and Rubenstein, J. L. (1997). Interneuron migration from basal forebrain to neocortex: dependence on Dlx genes. Science 278, 474-476. doi: 10.1126/science.278.5337.474

Ando, D., Kubo, Y., Akanuma, S., Yoneyama, D., Tachikawa, M., and Hosoya, K. (2012). Function and regulation of taurine transport in Muller cells under osmotic stress. Neurochem. Int. 60, 597-604. doi: 10.1016/j.neuint.2012.02.018

Araki, T., Kiyama, H., and Tohyama, M. (1992). GABA(A) receptor subunit messenger-RNAs show differential expression during cortical development in the rat-brain. Neuroscience 51, 583-591. doi: 10.1016/0306-4522 (92)90298-G

Banke, T. G., and McBain, C. J. (2006). GABAergic input onto CA3 hippocampal interneurons remains shunting throughout development. J. Neurosci. 26, 11720-11725. doi: 10.1523/JNEUROSCI.2887-06. 2006

Barbin, G., Pollard, H., Gaïarsa, J. L., and Ben-Ari, Y. (1993). Involvement of GABAA receptors in the outgrowth of cultured hippocampal neurons. Neurosci. Lett. 152, 150-154. doi: 10.1016/0304-3940(93)90505-F

Behar, T. N., Li, Y. X., Tran, H. T. Ma, W., Dunlap, V., Scott, C., et al. (1996). GABA stimulates chemotaxis and chemokinesis of embryonic cortical neurons via calcium-dependent mechanisms. J. Neurosci. 16, $1808-$ 1818.

Behar, T. N., Schaffner, A. E., Scott, C. A., Greene, C. L., and Barker, J. L. (2000). GABA receptor antagonists modulate postmitotic cell migration in slice cultures of embryonic rat cortex. Cereb. Cortex 10, 899-909. doi: 10.1093/cercor/10.9.899

Behar, T. N., Smith, S. V., Kennedy, R. T., McKenzie, J. M., Maric, I., and Barker, J. L. (2001). GABA(B) receptors mediate motility signals for migrating embryonic cortical cells. Cereb. Cortex 11, 744-753. doi: 10.1093/cercor/11.8.744

Ben-Ari, Y. (2002). Excitatory actions of GABA during development: the nature of the nurture. Nat Rev. Neurosci. 3, 728-739. doi: 10.1038/nrn920

Ben-Ari, Y., Cherubini, E., Corradetti, R., and Gaiarsa, J. L. (1989). Gian synaptic potentials in immature rat CA3 hippocampal neurones. J. Physiol. (Lond.) 416, 303-325.

Ben-Ari, Y., Gaiarsa, J. L., Tyzio, R. and Khazipov, R. (2007). GABA: a pioneer transmitter that excites immature neurons and generates primitive oscillations. Physiol. Rev. 87, 1215-1284. doi: 10.1152/physrev.00017.2006

Ben-Ari, Y., Woodin, M. A., Sernagor, E., Cancedda, L., Vinay, L., Rivera, C., et al. (2012). Refuting the challenges of the developmental shift of polarity of GABA actions: GABA more exciting than ever! Front. Cell. Neurosci. 6:35. doi: 10.3389/fncel.2012. 00035

Benitez-Diaz, P., Miranda-Contreras, L., Mendoza-Briceno, R. V., PenaContreras, Z., and Palacios-Pru, E. (2003). Prenatal and postnatal contents of amino acid neurotransmitters in mouse parietal cortex. Dev. Neurosci. 25, 366-374. doi: 10.1159/000073514

Bolea, S., Avignone, E., Berretta, N., Sanchez-Andres, J. V., and Cherubini, E. (1999). Glutamate controls the induction of GABA-mediated giant depolarizing potentials through AMPA receptors in neonatal rat hippocampal slices. J. Neurophysiol. 81, 2095-2102.

Borden, L. A. (1996). GABA transporter heterogeneity: pharmacology and cellular localization. Neurochem. Int. 29, 335-356. doi: 10.1016/01970186(95)00158-1

Bormann, J. (2000). The 'ABC' of GABA receptors. Trends Pharmacol. Sci. 21, 16-19. doi: 10.1016/S01656147(99)01413-3

Bragina, L., Marchionni, I., Omrani, A., Cozzi, A., Pellegrini-Giampietro, D.
E., Cherubini, E., et al. (2008). GAT1 regulates both tonic and phasic GABA(A) receptor-mediated inhibition in the cerebral cortex. $J$. Neurochem. 105, 1781-1793. doi: 10.1111/j.1471-4159.2008.05273.x

Brickley, S. G., and Mody, I. (2012). Extrasynaptic GABA(A) receptors: their function in the CNS and implications for disease. Neuron 73, 23-34. doi: 10.1016/j.neuron.2011.12.012

Caillard, O., McLean, H. A., BenAri, Y., and Gaïarsa, J. L. (1998) Ontogenesis of presynaptic GABAB receptor-mediated inhibition in the CA3 region of the rat hippocampus. J. Neurophysiol. 79, 1341-1348.

Cancedda, L., Fiumelli, H., Chen, K. and Poo, M. M. (2007). Excitatory GABA action is essential for morphological maturation of cortical neurons in vivo. J. $\mathrm{Neu}$ rosci. 27, 5224-5235. doi: 10.1523/ INEUROSCI.5169-06.2007

Carlson, V. C. C., and Yeh, H. H. (2011). $\mathrm{GABA}(\mathrm{A})$ receptor subunit profiles of tangentially migrating neurons derived from the medial ganglionic eminence. Cereb. Cortex 21, 17921802. doi: 10.1093/cercor/bhq247

Chan, S. O., Lyman, W. D., and Chiu, F. C. (1997). Temporal and spatial expression of glutamic acid decarboxylases in human fetal brain. Mol. Brain Res. 46, 318-320. doi: 10.1016/S0169-328X(97)00031-4

Clancy, B., Finlay, B. L., Darlington, R. B., and Anand, K. J. (2007). Extrapolating brain development from experimental species to humans. Neurotoxicology 28, 931-937. doi: 10.1016/j.neuro.2007.01.014

Cobas, A., Fairén, A., Alvarez-Bolado, G., and Sánchez, M. P. (1991). Prenatal development of the intrinsic neurons of the rat neocortex: a comparative study of the distribution of GABA-immunoreactive cells and the GABAA receptor. Neuroscience 40, 375-397. doi: 10.1016/0306 4522(91)90127-A

Conti, F., Minelli, A., and Melone, M. (2004). GABA transporters in the mammalian cerebral cortex: localization, development and pathological implications. Brain Res. Brain Res. Rev. 45, 196-212. doi: 10.1016/j.brainresrev.2004.03.003

Cuzon, V. C., Yeh, P. W., Cheng, Q., and Yeh, H. H. (2006). Ambient GABA promotes cortical entry of tangentially migrating cells derived from the medial ganglionic eminence. Cereb. Cortex 16, 1377-1388. doi: 10.1093/cercor/bhj084

Cuzon, V. C., Yeh, P. W., Yanagawa, Y., Obata, K., and Yeh, H. H. (2008). Ethanol consumption during early pregnancy alters the disposition of tangentially migrating GABAergic interneurons in the fetal cortex. J. Neurosci. 28, 1854-1864. doi: 10.1523/JNEUROSCI.5110-07.2008

Das, S. K., and Ray, P. K. (1997). Ontogeny of neurotransmitter amino acids in human fetal brains. Biochem. Mol. Biol. Int. 42, 193-202. doi: 10.1080/15216549700202581

Del Rio, J. A., Soriano, E., and Ferrer, I. (1992). Development of GABAimmunoreactivity in the neocortex of the mouse. J. Comp. Neurol. 326, 501526. doi: 10.1002/cne.903260403

Demarque, M., Represa, A., Becq, H., Khalilov, I., Ben Ari, Y., and Aniksztejn, L. (2002). Paracrine intercellular communication by a $\mathrm{Ca}^{2+}$ - and SNARE-independent release of GABA and glutamate prior to synapse formation. $\mathrm{Neu}$ ron 36, 1051-1061. doi: 10.1016/ S0896-6273(02)01053-X

Denter, D. G., Heck, N., Riedemann, T., White, R., Kilb, W., and Luhmann, H. J. (2010). $\mathrm{GABA}(\mathrm{C})$ receptors are functionally expressed in the intermediate zone and regulate radial migration in the embryonic mouse neocortex. Neuroscience 167, 124-134. doi: 10.1016/j.neuroscience.2010.01.049

Dupont, E., Hanganu, I. L., Kilb, W., Hirsch, S., and Luhmann, H. J. (2006). Rapid developmental switch in the mechanisms driving early cortical columnar networks. Nature 439, 79-83. doi: 10.1038/nature04264

Dupuy, S. T., and Houser, C. R. (1996). Prominent expression of two forms of glutamate decarboxylase in the embryonic and early postnatal rat hippocampal formation. J. Neurosci. 16, 6919-6932.

Duveau, V., Laustela, S., Barth, L., Gianolini, F., Vogt, K. E., Keist, R., et al. (2011). Spatiotemporal specificity of GABA(A) receptor-mediated regulation of adult hippocampal neurogenesis. Eur. J. Neurosci. 34, 362-373. doi: 10.1111/j.14609568.2011.07782.x

Dvorzhak, A., Myakhar, O., Unichenko, P., Kirmse, K., and Kirischuk, S. (2010). Estimation of ambient GABA levels in layer I of the mouse neonatal cortex in brain slices. J. Physiol. (Lond.) 588, 2351-2360. doi: 10.1113/jphysiol.2010.187054

Evans, J. E., Frostholm, A., and Rotter, A. (1996). Embryonic and postnatal expression of four gammaaminobutyric acid transporter mRNAs in the mouse brain and leptomeninges. J. Comp. Neurol. 376, 431-446. doi: 10.1002/(SICI)10969861(19961216)376:3 
Farrant, M., and Kaila, K. (2007). The cellular, molecular and ionic basis of $\mathrm{GABA}(\mathrm{A})$ receptor signalling. Prog. Brain Res. 160, 59-87. doi: 10.1016/S0079-6123(06)60005-8

Farrant, M., and Nusser, Z. (2005). Variations on an inhibitory theme: phasic and tonic activation of GABA(A) receptors. Nat. Rev. Neurosci. 6, 215-229. doi: 10.1038/nrn1625

Flint, A. C., Liu, X. L., and Kriegstein, A. R. (1998). Nonsynaptic glycine receptor activation during early neocortical development. Neuron 20, 4353. doi: 10.1016/S0896-6273(00)80 433-X

Fritschy, J. M., Paysan, J., Enna, A., and Mohler, H. (1994). Switch in the expression of rat GABAA-receptor subtypes during postnatal development: an immunohistochemical study. J. Neurosci. 14, 5302-5324.

Fu, Y., Wu, X. Y., Lu, J. T., and Huang, Z. J. (2012). Presynaptic $\mathrm{GABA}(\mathrm{B})$ receptor regulates activitydependent maturation and patterning of inhibitory synapses through dynamic allocation of synaptic vesicles. Front. Cell. Neurosci. 6:57. doi 10.3389/fncel.2012.00057

Fukuda, A., Mody, I., and Prince, D. A. (1993). Differential ontogenesis of presynaptic and postsynaptic GABAB inhibition in rat somatosensory cortex. J. Neurophysiol. 70, 448-452.

Fukui, M., Nakamichi, N., Yoneyama, M., Ozawa, S., Fujimori, S., Takahata, Y., et al. (2008). Modulation of cellular proliferation and differentiation through GABA(B) receptors expressed by undifferentiated neural progenitor cells isolated from fetal mouse brain. J. Cell. Physiol. 216, 507-519. doi: 10.1002/jcp.21422

Gaiarsa, J.-L., Tseeb, V., and BenAri, Y. (1995). Postnatal development of pre- and postsynaptic GABABmediated inhibitions in the $\mathrm{CA} 3$ hippocampal region of the rat. $J$. Neurophysiol. 73, 246-255.

Garaschuk, O., Hanse, E., and Konnerth, A. (1998). Developmental profile and synaptic origin of early network oscillations in the CAl region of rat neonatal hippocampus. J. Physiol. (Lond.) 507, 219 236. doi: 10.1111/j.1469-7793.1998. 219bu.x

Hartmann, K., Stief, F., Draguhn, A., and Frahm, C. (2004). Ionotropic GABA receptors with mixed pharmacological properties of GABAA and GABAC receptors. Eur. J. Pharmacol. 497, 139-146. doi: 10.1016/j.ejphar.2004.06.044

Haydar, T. F., Wang, F., Schwartz, M. L., and Rakic, P. (2000). Differential modulation of proliferation in the neocortical ventricular and subventricular zones. J. Neurosci. 20, 5764-5774.

Heck, N., Kilb, W., Reiprich, P., Kubota, H., Furukawa, T., Fukuda, A., et al. (2007). GABA-A receptors regulate neocortical neuronal migration in vitro and in vivo. Cereb. Cortex 17 138-148. doi: 10.1093/cercor/bhj135

Heng, J. I., Moonen, G., and Nguyen, L. (2007). Neurotransmitters regulate cell migration in the telencephalon. Eur. J. Neurosci. 26, 537-546. doi: 10.1111/j.1460-9568.2007.05694.x

Hennou, S., Khalilov, I., Diabira, D., Ben-Ari, Y., and Gozlan, H. (2002). Early sequential formation of functional $\operatorname{GABA}(\mathrm{A})$ and glutamatergic synapses on CA1 interneurons of the rat foetal hippocampus. Eur. J. Neurosci. 16, 197-208. doi: $\quad 10.1046 /$ j.1460-9568.2002.02 073. $\mathrm{x}$

Hill, J., Inder, T., Neil, J., Dierker, D., Harwell, J., and Van Essen, D. (2010). Similar patterns of cortical expansion during human development and evolution. Proc. Natl. Acad. Sci. U.S.A. 107, 13135-13140. doi: 10.1073/pnas.1001229107

Holter, N. I., Zylla, M. M., Zuber, N., Bruehl, C., and Draguhn, A. (2010). Tonic GABAergic control of mouse dentate granule cells during postnatal development. Eur. J. Neurosci. 32, 1300-1309. doi: 10.1111/j.14609568.2010.07331.x

Hornung, J. P., and Fritschy, J. M. (1996). Developmental profile of $\operatorname{GABA}(\mathrm{A})$-receptors in the marmoset monkey: expression of distinct subtypes in pre- and postnatal brain. J. Comp. Neurol. 367, 413-430. doi: 10.1002/(SICI)10969861(19960408)367:3

Huntsman, M. M., Munoz, A., and Jones, E. G. (1999). Temporal modulation of $\mathrm{GABA}(\mathrm{A})$ receptor subunit gene expression in developing monkey cerebral cortex. Neuroscience 91, 1223-1245. doi: 10.1016/S03064522(98)00713-1

Inada, H., Watanabe, M., Uchida, T., Ishibashi, H., Wake, H., Nemoto, T., et al. (2011). GABA regulates the multidirectional tangential migration of GABAergic interneurons in living neonatal mice. PLoS ONE 6:e27048. doi: 10.1371/journal.pone. 0027048

Jacobs, J. S., and Miller, M. W. (2001). Proliferation and death of cultured fetal neocortical neurons: effects of ethanol on the dynamics of cell growth. J. Neurocytol. 30, 391-401. doi: 10.1023/A:1015013609424

Ji, F. Y., Kanbara, N., and Obata, K. (1999). GABA and histogenesis in fetal and neonatal mouse brain lacking both the isoforms of glutamic acid decarboxylase. Neurosci. Res. 33, 187-194. doi: 10.1016/S01680102(99)00011-5

Kanold, P. O., and Luhmann, H. J. (2010). The subplate and early cortical circuits. Annu. Rev. Neurosci. 33, 23-48. doi: 10.1146/annurev-neuro060909-153244

Khazipov, R., and Luhmann, H. J. (2006). Early patterns of electrical activity in the developing cerebral cortex of human and rodents. Trends Neurosci. 29, 414-418. doi: 10.1016/j.tins.2006.05.007

Kilb, W. (2012). Development of the GABAergic system from birth to adolescence. Neuroscientist 18, 613-630. doi: 10.1177/1073858411422114

Kilb, W., Hanganu, I. L., Okabe, A., Sava, B. A., Shimizu-Okabe, C., Fukuda, A., et al. (2008). Glycine receptors mediate excitation of subplate neurons in neonatal rat cerebral cortex. J. Neurophysiol. 100, 698-707. doi: 10.1152/jn.00657.2007

Kilb, W., Hartmann, D., Saftig, P. and Luhmann, H. J. (2004). Altered morphological and electrophysiological properties of Cajal-Retzius cells in cerebral cortex of embryonic presenilin-1 knockout mice. Eur. J. Neurosci. 20, 2749-2756. doi: $\quad 10.1111 /$ j.1460-9568.2004.03 732. $\mathrm{x}$

Kilb, W., Ikeda, M., Uchida, K. Okabe, A., Fukuda, A., and Luhmann, H. J. (2002). Depolarizing glycine responses in Cajal-Retzius cells of neonatal rat cerebral cortex. Neuroscience 112, 299-307. doi: 10.1016/S0306-4522(02)00071-4

Kilb, W., Kirischuk, S., and Luhmann, H. J. (2011). Electrical activity patterns and the functional maturation of the neocortex. Eur. J. Neurosci. 34, 1677-1686. doi: 10.1111/j.1460 9568.2011.07878.x

Killisch, I., Dotti, C. G., Laurie, D. J., Luddens, H., and Seeburg, P. H. (1991). Expression patterns of GABAA receptor subtypes in developing hippocampal neurons. Neuron 7, 927-936. doi: 10.1016/0896 6273(91)90338-Z

Kirischuk, S., and Kilb, W. (2012). "GAT (GABA transporters)," in Encyclopedia of Signaling Molecules, ed. C. Sangdun (New York, NY: Springer), 756-760.

Kirmse, K., and Kirischuk, S (2006). Ambient GABA constrains the strength of GABAergic synapses at Cajal-Retzius cells in the developing visual cortex. J. Neurosci. 26, 4216-4227. doi: 10.1523/JNEUROSCI.0589-06.2006
Kirsch, J., Malosio, M. L., Wolters, I., and Betz, H. (1993). Distribution of gephyrin transcripts in the adult and developing rat brain. Eur. J. Neurosci. 5, 1109-1117. doi: 10.1111/j.14609568.1993.tb00965.x

Kiser, P. J., Cooper, N. G., and Mower, G. D. (1998). Expression of two forms of glutamic acid decarboxylase (GAD67 and GAD65) during postnatal development of rat somatosensory barrel cortex. J. Comp. Neurol. 402, 62-74. doi: 10.1002/(SICI) 1096 9861(19981207)402:1

Kneussel, M., and Betz, H. (2000). Clustering of inhibitory neurotransmitter receptors at developing postsynaptic sites: the membrane activation model. Trends Neurosci. 23, 429435. doi: 10.1016/S0166-2236(00) 01627-1

Kneussel, M., Engelkamp, D., and Betz, H. (2001). Distribution of transcripts for the brain-specific GDP/GTP exchange factor collybistin in the developing mouse brain. Eur. J. Neurosci. 13, 487-492. doi: 10.1046/j.0953-816x.2000.01411.x

Kolbaev, S. N., Achilles, K., Luhmann, H. J., and Kilb, W. (2011). Effect of depolarizing GABA(A)-mediated membrane responses on excitability of Cajal-Retzius cells in the immature rat neocortex. J. $\mathrm{Neu}$ rophysiol. 106, 2034-2044. doi: 10.1152/jn.00699.2010

Kolbaev, S. N., Sharopov, S., Dierkes, P. W., Luhmann, H. J., and Kilb, W. (2012). Phasic GABAA-receptor activation is required to suppress epileptiform activity in the CA3 region of the immature rat hippocampus. Epilepsia 53, 888-896. doi: 10.1111/j.1528-1167.2012.03442.x

Komuro, H., and Rakic, P. (1996). Intracellular $\mathrm{Ca}^{2+}$ fluctuations modulate the rate of neuronal migration. $\mathrm{Neu}$ ron 17, 275-285. doi: 10.1016/S08966273(00)80159-2

Kristt, D. A., and Waldman, J. V. (1986). Late postnatal changes in rat somatosensory cortex. Temporal and spatial relationships of GABA-T and AChE histochemical reactivity. Anat. Embryol. (Berl.) 174, 115-122. doi: 10.1007/BF00318343

Lamsa, K., Palva, J. M., Ruusuvuori, E., Kaila, K., and Taira, T. (2000). Synaptic GABA(A) activation inhibits AMPA-kainate receptormediated bursting in the newborn (P0-P2) rat hippocampus. J. Neurophysiol. 83, 359-366.

Lauder, J. M., Han, V. K., Henderson, P., Verdoorn, T., and Towle, A. C. (1986). Prenatal ontogeny of the GABAergic system in the rat brain: an immunocytochemical 
study. Neuroscience 19, 465-493. doi: 10.1016/0306-4522(86)90275-7

Laurie, D. J., Wisden, W., and Seeburg, P. H. (1992). The distribution of thirteen GABAA receptor subunit mRNAs in the rat brain. III. Embryonic and postnatal development. J. Neurosci. 12, 4151-4172.

Leinekugel, X., Medina, I., Khalilov, I., Ben Ari, Y., and Khazipov, R. (1997). $\mathrm{Ca}^{2+}$ oscillations mediated by the synergistic excitatory actions of GABA(A) and NMDA receptors in the neonatal hippocampus. Neuron 18, 243-255. doi: 10.1016/S08966273(00)80265-2

Li, S. P., Park, M. S., and Kim, M. O. (2004). Prenatal alteration and distribution of the $\operatorname{GABA}(\mathrm{B} 1)$ and $\operatorname{GABA}(\mathrm{B} 2)$ receptor subunit mRNAs during rat central nervous system development. Dev. Brain Res. 150, 141-150. doi: 10.1016/j.devbrainres.2004.03.009

Liu, X., Wang, Q., Haydar, T. F., and Bordey, A. (2005). Nonsynaptic GABA signaling in postnatal subventricular zone controls proliferation of GFAP-expressing progenitors. Nat. Neurosci. 8, 1179-1187. doi: $10.1038 / \mathrm{nn} 1522$

López-Bendito, G., Lujan, R., Shigemoto, R., Ganter, P., Paulsen, O., and Molnár, Z. (2003). Blockade of GABA-B receptors alters the tangential migration of cortical neurons. Cereb. Cortex 13, 932-942. doi: 10.1093/cercor/13.9.932

López-Bendito, G., Shigemoto, R., Kulik, A., Paulsen, O., Fairen, A., and Lujan, R. (2002). Expression and distribution of metabotropic GABA receptor subtypes GABA-BR1 and GABA-BR2 during rat neocortical development. Eur. J. Neurosci. 15, 1766-1778. doi: 10.1046/j.14609568.2002.02032.x

LoTurco, J. J., Owens, D. F., Heath, M. J., Davis, M. B., and Kriegstein, A. R. (1995). GABA and glutamate depolarize cortical progenitor cells and inhibit DNA synthesis. Neuron 15, 1287-1298. doi: 10.1016/08966273(95)90008-X

Luddens, H., Pritchett, D. B., Kohler, M., Killisch, I., Keinanen, K., Monyer, H., et al. (1990). Cerebellar GABAA receptor selective for a behavioural alcohol antagonist. Nature 346, 648651. doi: 10.1038/346648a0

Luhmann, H. J., and Prince, D. A. (1991). Postnatal maturation of the GABAergic system in rat neocortex. J. Neurophysiol. 65, 247-263.

Luyt, K., Slade, T. P., Dorward, J. J., Durant, C. F., Wu, Y., Shigemoto, R., et al. (2007). Developing oligodendrocytes express functional GABA(B) receptors that stimulate cell proliferation and migration. J. Neurochem. 100, 822-840. doi: 10.1111/j.14714159.2006.04255.x

Ma, Q. F. (2006). Transcriptional regulation of neuronal phenotype in mammals. J. Physiol. (Lond.) 575, 379-387. doi: 10.1113/jphysiol.2006.113449

Ma, W., and Barker, J. L. (1995). Complementary expressions of transcripts encoding $\operatorname{Gad}(67)$ and Gaba(A) receptor alpha-4, beta-1, and gamma-1 subunits in the proliferative zone of the embryonic rat central nervous system. J. Neurosci. 15, 2547-2560.

MacLennan, A. J., Brecha, N., Khrestchatisky, M., Sternini, C. Tillakaratne, N. J. K., Chiang, M. Y., et al. (1991). Independent cellular and ontogenic expression of messenger-Rnas encoding 3 alpha polypeptides of the rat GABA-A receptor. Neuroscience 43, 369-380. doi: 10.1016/0306-4522(91)90301-4

Manent, J. B., Demarque, M., Jorquera, I., Pellegrino, C., Ben Ari, Y., Aniksztejn, L., et al. (2005). A noncanonical release of GABA and glutamate modulates neuronal migration. J. Neurosci. 25, 4755-4765. doi: 10.1523/ JNEUROSCI.0553-05.2005

Manent, J. B., Jorquera, I., Mazzucchelli, I., Depaulis, A., Perucca, E., Ben Ari, Y., et al. (2007). Fetal exposure to GABA-acting antiepileptic drugs generates hippocampal and cortical dysplasias. Epilepsia 48, 684-693. doi: 10.1111/j.1528-1167.2007.01056.x

Manent, J. B., and Represa, A. (2007). Neurotransmitters and brain maturation: early paracrine actions of GABA and glutamate modulate neuronal migration. Neuroscientist 13, 268-279. doi: $10.1177 / 1073858406298918$

Marchionni, I., Omrani, A., and Cherubini, E. (2007). In the developing rat hippocampus a tonic GABAAmediated conductance selectively enhances the glutamatergic drive of principal cells. J. Physiol. (Lond.) 581, 515-528. doi: 10.1113/jphysiol.2006.125609

Maric, D., Liu, Q. Y., Maric, I., Chaudry, S., Chang, Y. H., Smith, S. V., et al. (2001). GABA expression dominates neuronal lineage progression in the embryonic rat neocortex and facilitates neurite outgrowth via GABAA autoreceptor $/ \mathrm{Cl}^{-}$channels. J. Neurosci. 21, 2343-2360.

Maric, D., Maric, I., Wen, X. L., Fritschy, J. M., Sieghart, W., Barker, J. L., et al. (1999). GABAA receptor subunit composition and functional properties of $\mathrm{Cl}^{-}$channels with differential sensitivity to zolpidem in embryonic rat hippocampal cells. $J$ Neurosci. 19, 4921-4937.

McClellan, K. M., Calver, A. R. and Tobet, S. A. (2007). GABA(B) receptors role in cell migration and positioning within the ventromedial nucleus of the hypothalamus. Neuroscience 151, 1119-1131. doi: 10.1016/j.neuroscience.2007.11.048

Minelli, A., Alonso-Nanclares, L., Edwards, R. H., DeFelipe, J., and Conti, F. (2003). Postnatal development of the vesicular GABA transporter in rat cerebral cortex. Neuroscience 117, 337-346. doi: 10.1016/S0306-4522(02)00864-3

Miyoshi, G., Hjerling-Leffler, J. Karayannis, T., Sousa, V. H., Butt, S. J., Battiste, J., et al. (2010) Genetic fate mapping reveals that the caudal ganglionic eminence produces a large and diverse population of superficial cortical interneurons. J. Neurosci. 30, 1582-1594. doi: 10.1523/JNEUROSCI.4515-09.2010

Mori, M., Gahwiler, B. H., and Gerber, U. (2002). Beta-alanine and taurine as endogenous agonists at glycine receptors in rat hippocampus in vitro 41. J. Physiol. (Lond.) 539, 191-200. doi: 10.1113/jphysiol.2001.013147

Mueller, A. L., Taube, J. S., and Schwartzkroin, P. A. (1984). Development of hyperpolarizing inhibitory postsynaptic potentials and hyperpolarizing response to gamma-aminobutyric acid in rabbit hippocampus studied in vitro. J. Neurosci. 4, 860-867.

Mukherjee, J., Kretschmannova, K., Gouzer, G., Maric, H. M., Ramsden, S., Tretter, V., et al. (2011). The residence time of GABA(A)Rs at inhibitory synapses is determined by direct binding of the receptor alpha 1 subunit to gephyrin. J. Neurosci. 31, 14677-14687. doi: 10.1523/JNEUROSCI.2001-11.2011

Nimmervoll, B., Denter, D. G., Sava, I., Kilb, W., and Luhmann, H. J. (2011). Glycine receptors influence radial migration in the embryonic mouse neocortex. Neuroreport 22, 509-513. doi: 10.1097/WNR.0b013e328348aafe

Noctor, S. C., Flint, A. C., Weissman, T. A., Dammerman, R. S., and Kriegstein, A. R. (2001). Neurons derived from radial glial cells establish radial units in neocortex. Nature 409, 714-720. doi: 10.1038/ 35055553

Noctor, S. C., Flint, A. C., Weissman, T. A., Wong, W. S., Clinton, B. K. and Kriegstein, A. R. (2002). Dividing precursor cells of the embryonic cortical ventricular zone have morphological and molecular characteristics of radial glia. J. Neurosci. 22, 3161-3173.

Okabe, A., Kilb, W., Shimizu-Okabe, C., Hanganu, I. L., Fukuda, A., and Luhmann, H. J. (2004). Homogenous glycine receptor expression in cortical plate neurons and Cajal-Retzius cells of neonatal rat cerebral cortex. Neuroscience 123, 715-724. doi: 10.1016/j.neuroscience.2003.10.014

Owens, D. F., Boyce, L. H., Davis, M. B., and Kriegstein, A. R. (1996). Excitatory GABA responses in embryonic and neonatal cortical slices demonstrated by gramicidin perforated-patch recordings and calcium imaging. J. Neurosci. 16, 64146423.

Owens, D. F., and Kriegstein, A. R. (2002). Is there more to GABA than synaptic inhibition? Nat. Rev. Neurosci. 3, 715-727. doi: 10.1038/nrn919

Owens, D. F., Liu, X. L., and Kriegstein, A. R. (1999). Changing properties of GABAA receptor-mediated signaling during early neocortical development. J. Neurophysiol. 82, 570-583.

Palackal, T., Moretz, R., Wisniewski, H., and Sturman, J. (1986). Abnormal visual cortex development in the kitten associated with maternal dietary taurine deprivation. J. Neurosci. Res. 15, 223-239. doi: 10.1002/jnr.490150212

Petanjek, Z., Dujmovic, A., Kostovic, I., and Esclapez, M. (2008). Distinct origin of GABA-ergic neurons in forebrain of man, nonhuman primates and lower mammals. Coll. Antropol. 32, 9-17.

Pin, J. P., and Bockaert, J. (1989). Two distinct mechanisms, differentially affected by excitatory aminoacids, trigger GABA release from fetal mouse striatal neurons in primary culture. J. Neurosci. 9, 648-656.

Pitts, F. N. Jr., and Quick, C. (1967). Brain succinate semialdehyde. II. Changes in the developing rat brain. J. Neurochem. 14, 561-570. doi: 10.1111/j.1471-4159.1967.tb09556.x

Pleasure, S. J., Anderson, S., Hevner, R., Bagri, A., Marin, O., Lowenstein, D. H., et al. (2000). Cell migration from the ganglionic eminences is required for the development of hippocampal GABAergic interneurons. Neuron 28, 727-740. doi: 10.1016/S08966273(00)00149-5

Poluch, S., and Konig, N. (2002). AMPA receptor activation induces GABA release from neurons migrating tangentially in the intermediate zone of embryonic rat neocortex. Eur. J. Neurosci. 16, 350-354. doi: 10.1046/j.1460-9568.2002.02068.x 
Poulter, M. O., Barker, J. L., Ocarroll, A. M., Lolait, S. J., and Mahan, L. C. (1992). Differential and transient expression of GABA-A receptor alpha-subunit messenger-Rnas in the developing rat Cns. J. Neurosci. 12, 2888-2900.

Ramos, B., Lopez-Tellez, J. F., Vela, J., Baglietto-Vargas, D., del Rio, J. C., Ruano, D., et al. (2004). Expression of alpha 5 GABA(A) receptor subunit in developing rat hippocampus. Dev. Brain Res. 151, 87-98. doi: 10.1016/j.devbrainres.2004.04.003

Represa, A., and Ben-Ari, Y. (2005). Trophic actions of GABA on neuronal development. Trends Neurosci. 28, 278-283. doi: 10.1016/j.tins.2005. 03.010

Richerson, G. B., and Wu, Y. (2003). Dynamic equilibrium of neurotransmitter transporters: not just for reuptake anymore. J. Neurophysiol. 90, 1363-1374. doi: 10.1152/ jn. 00317.2003

Romijn, H. J., Hofman, M. A., and Gramsbergen, A. (1991). At what age is the developing cerebral cortex of the rat comparable to that of the full-term newborn human baby? Early Hum. Dev. 26, 61-67. doi: 10.1016/0378-3782(91)90044-4

Romo-Parra, H., Vivar, C., Maqueda, J., Morales, M. A., and Gutierrez, R. (2003). Activity-dependent induction of multitransmitter signaling onto pyramidal cells and interneurons of hippocampal area CA3. J. Neurophysiol. 89, 3155-3167. doi: 10.1152/jn.00985.2002

Root, C. M., Velazquez-Ulloa, N. A., Monsalve, G. C., Minakova, E., and Spitzer, N. C. (2008). Embryonically expressed GABA and glutamate drive electrical activity regulating neurotransmitter specification. J. Neurosci. 28, 4777-4784. doi: 10.1523/JNEUROSCI.4873-07. 2008

Rozzo, A., Armellin, M., Franzot, J., Chiaruttini, C., Nistri, A., and Tongiorgi, E. (2002). Expression and dendritic mRNA localization of GABA(C) receptor rho 1 and rho 2 subunits in developing rat brain and spinal cord. Eur. J. Neurosci. 15, 1747-1758. doi: 10.1046/j.14609568.2002.02013.x

Safiulina, V. F., and Cherubini, E. (2009). At immature mossy fibers-CA3 connections, activation of presynaptic $\mathrm{GABA}(\mathrm{B})$ receptors by endogenously released GABA contributes to synapses silencing. Front. Cell. Neurosci. 3:1. doi: 10.3389/fncel.2009.00001

Semyanov, A., and Kullmann, D. M. (2002). Relative picrotoxin insensitivity distinguishes ionotropic GABA receptor-mediated IPSCs in hippocampal interneurons. Neuropharmacology 43, 726-736. doi 10.1016/S0028-3908(02)00123-5

Semyanov, A., Walker, M. C., and Kullmann, D. M. (2003). GABA uptake regulates cortical excitability via cell type-specific tonic inhibition. Nat. Neurosci. 6, 484-490. doi:10.1038/nn1043

Sernagor, E., Chabrol, F., Bony, G., and Cancedda, L. (2010). GABAergic control of neurite outgrowth and remodeling during development and adult neurogenesis: general rules and differences in diverse systems. Front. Cell. Neurosci. 4:11. doi: 10.3389/fncel.2010.00011

Shen, J. M., Huguenard, J. R., and Kriegstein, A. R. (1988). Development of GABA responsiveness in embryonic turtle cortical neurons. Neurosci. Lett. 89, 335-341. doi: 10.1016/03043940(88)90549-6

Sipila, S., Huttu, K., Voipio, J., and Kaila, K. (2004). GABA uptake via GABA transporter-1 modulates GABAergic transmission in the immature hippocampus. $J$ Neurosci. 24, 5877-5880. doi: 10.1523/JNEUROSCI.1287-04.2004

Sipila, S. T., Huttu, K., Soltesz, I., Voipio, J., and Kaila, K. (2005). Depolarizing GABA acts on intrinsically bursting pyramidal neurons to drive giant depolarizing potentials in the immature hippocampus. J. Neurosci. 25, 5280-5289. doi: 10.1523/JNEUROSCI.0378-05.2005

Sipila, S. T., Huttu, K., Voipio, J., and Kaila, K. (2006). Intrinsic bursting of immature CA3 pyramidal neurons and consequent giant depolarizing potentials are driven by a persistent $\mathrm{Na}$ current and terminated by a slow Ca-activated K current. Eur. J. Neurosci. 23, 2330-2338. doi: 10.1111/j.1460-9568.2006.04757.x

Sipila, S. T., Voipio, J., and Kaila, K. (2007). GAT-1 acts to limit a tonic GABA(A) current in rat CA3 pyramidal neurons at birth. Eur. J. Neurosci. 25, 717-722. doi: 10.1111/j.14609568.2007.05342.x

Soghomonian, J. J., and Martin, D. L. (1998). Two isoforms of glutamate decarboxylase: why? Trends Pharmacol. Sci. 19, 500-505. doi: 10.1016/S0165-6147(98)01270-X

Song, I., Volynski, K., Brenner, T., Ushkaryov, Y., Walker, M., and Semyanov, A. (2013). Different transporter systems regulate extracellular GABA from vesicular and non-vesicular sources. Front. Cell. Neurosci. 7:23. doi: 10.3389/fncel.2013.00023
Song, I. S., Savtchenko, L., and Semyanov, A. (2011). Tonic excitation or inhibition is set by GABA(A) conductance in hippocampal interneurons. Nat. Commun. 2, 376. doi: 10.1038/ncomms1377

Soriano, E., Del Rio, J. A., Martinez, A., and Super, H. (1994). Organization of the embryonic and early postnatal murine hippocampus. I. Immunocytochemical characterization of neuronal populations in the subplate and marginal zone. $J$. Comp. Neurol. 342, 571-595. doi: 10.1002/cne.903420406

Tricoire, L., Pelkey, K. A., Erkkila, B. E., Jeffries, B. W., Yuan, X. Q., and McBain, C. J. (2011). A blueprint for the spatiotemporal origins of mouse hippocampal interneuron diversity. J. Neurosci. 31, 10948-10970. doi: 10.1523/JNEUROSCI.0323-11.2011

Tyzio, R., Represa, A., Jorquera, I., Ben-Ari, Y., Gozlan, H., and Aniksztejn, L. (1999). The establishment of GABAergic and glutamatergic synapses on CAl pyramidal neurons is sequential and correlates with the development of the apical dendrite. J. Neurosci. 19 10372-10382.

Ulrich, D., and Bettler, B. (2007). GABA(B) receptors: synaptic functions and mechanisms of diversity. Curr. Opin. Neurobiol. 17, 298-303. doi: 10.1016/j.conb.2007.04.001

Valeeva, G., Abdullin, A., Tyzio, R., Skorinkin, A., Nikolski, E., Ben-Ari, Y., et al. (2010). Temporal coding at the immature depolarizing GABAergic synapse. Front. Cell. Neurosci. 4:17. doi: 10.3389/fncel.2010.00017

Valeeva, G., Valiullina, F., and Khazipov, R. (2013). Excitatory actions of GABA in the intact neonatal rodent hippocampus in vitro. Front. Cell. Neurosci. 7:20. doi: 10.3389/fncel.2013.00020

Valeyev, A. Y., Schaffner, A. E., Skolnick, P., Dunlap, V. S., Wong, G. and Barker, J. L. (1998). Embryonic rat hippocampal neurons and GABAA receptor subunit-transfected non-neuronal cells release GABA tonically. J. Membr. Biol. 164, 239251. doi: $10.1007 / \mathrm{s} 002329900409$

Van Eden, C. G., Mrzljak, L., Voorn, P., and Uylings, H. B. M. (1989). Prenatal development of GABA-ergic neurons in the neocortex of the rat. J. Comp. Neurol. 289, 213-227. doi 10.1002/cne. 902890204

Van Eden, C. G., Parmar, R., Lichtensteiger, W., and Schlumpf, M. (1995). Laminar distribution of GABAA receptor $\alpha 1, \beta 2$, and gamma 2 subunit mRNAs in the granular and agranular frontal cortex of the rat during pre- and postnatal development. Cereb. Cortex 5, 234-246. doi: 10.1093/cercor/5.3.234

Varju, P., Katarova, Z., Madarasz, E., and Szabo, G. (2001). GABA signalling during development: new data and old questions. Cell Tissue Res. 305, 239-246. doi: 10.1007/s004410100356

Verhage, M., Maia, A. S., Plomp, J. J., Brussaard, A. B., Heeroma, J. H., Vermeer, H., et al. (2000). Synaptic assembly of the brain in the absence of neurotransmitter secretion. Science $287,864-869$. doi: $10.1126 /$ science.287.5454.864

Wang, D. D., and Kriegstein, A. R. (2008). GABA regulates excitatory synapse formation in the neocortex via NMDA receptor activation. J. Neurosci. 28, 5547-5558. doi: 10.1523/JNEUROSCI.5599-07.2008

Wang, D. D., and Kriegstein, A. R. (2009). Defining the role of GABA in cortical development. J. Physiol. (Lond.) 587, 1873-1879. doi: 10.1113/jphysiol.2008.167635

Wojcik, S. M., Katsurabayashi, S., Guillemin, I., Friauf, E., Rosenmund, C., Brose, N., et al. (2006). A shared vesicular carrier allows synaptic corelease of GABA and glycine. Neuron 50, 575-587. doi: 10.1016/j.neuron.2006.04.016

Wu, W. L., Ziskind-Conhaim, L., and Sweet, M. A. (1992). Early development of glycine- and GABAmediated synapses in rat spinal cord. J. Neurosci. 12, 3935-3945.

Yan, X. X., Cariaga, W. A., and Ribak, C. E. (1997). Immunoreactivity for GABA plasma membrane transporter, GAT- 1, in the developing rat cerebral cortex: transient presence in the somata of neocortical and hippocampal neurons. Dev. Brain Res. 99, 1-19. doi: 10.1016/S01653806(96)00192-7

Yu, X. J., and Zecevic, N. (2011). Dorsal radial glial cells have the potential to generate cortical interneurons in human but not in mouse brain J. Neurosci. 31, 2413-2420. doi 10.1523/JNEUROSCI.5249-10.2011

Zecevic, N., and Milosevic, A. (1997). Initial development of gamma-aminobutyric acid immunoreactivity in the human cerebral cortex. J. Comp. Neurol. 380, 495-506. doi: 10.1002/(SICI) 10969861(19970421)380:4

Conflict of Interest Statement: The authors declare that the research was conducted in the absence of any commercial or financial relationships that could be construed as a potential conflict of interest. 
Received: 14 June 2013; paper pending published: 04 July 2013; accepted: 16 August 2013; published online: 03 September 2013.

Citation: Kilb W, Kirischuk $S$ and Luhmann HJ (2013) Role of tonic
GABAergic currents during pre- and early postnatal rodent development. Front. Neural Circuits 7:139. doi: 10.3389/fncir.2013.00139

This article was submitted to the journal Frontiers in Neural Circuits.
Copyright (c) 2013 Kilb, Kirischuk and Luhmann. This is an open-access article distributed under the terms of the Creative Commons Attribution License (CC BY). The use, distribution or reproduction in other forums is permitted, provided the original author(s) or licensor are credited and that the original publication in this journal is cited, in accordance with accepted academic practice. No use, distribution or reproduction is permitted which does not comply with these terms. 